\title{
РАЗРАБОТКА ТЕХНОЛОГИИ ТВОРОЖНОГО ПРОДУКТА С ИСПОЛЬЗОВАНИЕМ СУХОЙ ПАХТЫ
}

\author{
Ю.К. Насонова, Т.П. Арсеньева, Е.А. Рощина, \\ В.С. Мухамедова, А.И. Лепешкин
}

\begin{abstract}
Данная статья рассматривает возможность применения восстановленной пахты при производстве творожных продуктов с адаптированным белковым составом и пониженной жирностью. Предлагаемая технология позволит сократить расход сырья и продолжительность технологического процесса получения творога, за счет отсутствия необходимости дополнительного отделения сыворотки после формирования сгустка. Более полное использование составных частей молока позволит расширить ассортимент продукции, будет способствовать росту технико-экономических показателей и производительности труда молочных предприятий. В качестве объектов исследований выступали обезжиренное молоко, сухая пахта с массовой долей жира 6\% и закваска для творога в количестве 5 и 10\%, состоящая из культур Lactococcuslactissubsp. lactis, Lactacoccus lactis subsp.cremoris, Streptococcus thermohilus.. По классической технологии производства творога, массовая доля сухих веществ в сгустке составляет 8-9\%, нами при составлении нормализованной смеси подбиралась такая концентрация сухих веществ, которая позволит исключить технологическую операцию отделения сыворотки и при которой готовый продукт будет не уступать по показателям качества творогу, полученному по традиционной технологии. Результаты исследований по определению органолептических и фризико-химических показателей, а так же расчет биологической ценности белковой составляющей полученных сгустков позволили сделать вывод о целесообразности проведения дальнейших исследований предлагаемой технологии.

Ключевые слова: творожные продукты, пахта, ресурсосберегающие технологии, разработка рецептур, технологии продуктов питания.
\end{abstract}

В настоящее время значительный научный и практический интерес представляет разработка ресурсосберегающих технологий производства творога и творожных продуктов, позволяющих сократить расход сырья и получить традиционно востребованные продукты, удовлетворяющие принципам безопасности, функциональности и экологичности.

Молочная промышленность в настоящее время испытывает постоянный дефицит ресурсов, который ограничивает возможность качественного и количественного развития производства. На фоне нехватки сырья и как следствие недозагруженности мощностей, для российских предприятий становится актуальным вопрос полного и рационального использования вторичных сырьевых ресурсов молочной промышленности (обезжиренное молоко, пахта, молочная сыворотка). Более полное использование составных частей молока позволит расширить ассортимент продукции, будет способствовать росту техникоэкономических показателей и производительности труда молочных предприятий. Значительные объёмы, питательная и биолоПОЛЗУНОВСКИЙ ВЕСТНИК № 32018 гическая ценность обусловливают необходимость сбора и использования обезжиренного молока, пахты и молочной сыворотки.

Пахта - биологически активный обезжиренный, получаемый как остаток после сбивания сливочного масла. Пахта достаточно широко используется в ряде стран с развитой молочной промышленностью для производства различных диетических натуральных и кисломолочных напитков, а также их разнообразных подвидов с наполнителями и ароматизаторами, сухих и сгущенных концентратов, детского питания и добавок в пищевые продукты. Для пролонгирования сроков хранения, а так же для более полноценного использования имеющихся ресурсов пахты, особенно в сезон массовой переработки молока, на сливочное масло, возможно производство концентратов из пахты. Химический состав сухой пахты представлен в таблице 1.

Состав пахты похож на состав обезжиренного молока, за исключением присутствия остаточного жира и компонентов оболочек жировых шариков, таких как фосффолипиды, сфинголипиды и гликопротеины [1]. 


\section{Ю.К. НАСОНОВА, Т.П. АРСЕНЬЕВА, Е.А. РОЩИНА, В.С. МУХАМЕДОВА, А.И. ЛЕПЕШКИН}

Таблица 1 - Химический состав сухой пахты с массовой долей жира $6 \%$

\begin{tabular}{|l|c|c|c|}
\hline \multicolumn{4}{|c|}{ Пищевые вещества, г/100г } \\
\hline Белки & 34,3 & $\begin{array}{c}\text { Угле- } \\
\text { воды }\end{array}$ & 49,00 \\
\hline Жиры & 5,78 & Зола & 7,95 \\
\hline Минеральные вещества, мг \\
\hline $\mathrm{Na}$ & 517 & $\mathrm{Mg}$ & 110 \\
\hline $\mathrm{K}$ & 1592 & $\mathrm{P}$ & 933 \\
\hline $\mathrm{Ca}$ & 1184 & \\
\hline \multicolumn{4}{|c|}{ Витамины, мг } \\
\hline А & 0,049 & $\mathrm{~B} 4$ & 118,7 \\
\hline Е & 0,1 & В5 & 3,17 \\
\hline С & 5,7 & В6 & 0,34 \\
\hline В1 & 0,39 & В9 & 0,047 \\
\hline В2 & 1,58 & В12 & 0,004 \\
\hline Энергетическая ценность, ккал & 387 \\
\hline
\end{tabular}

Концентрация фосфолипидов в пахте составляет около 0,091\% по сравнению с $0,029 \%$ в цельном молоке, а соотношение фоссролипидов к общему липидам намного выше [2]. Ряд зарубежных ученых уделял внимание исследованию влияния фоосфолипидов на здоровье человека. Сфингомиелин может оказывать противоопухолевое действие, влияя на пролиферацию клеток и подавляя развитие опухолей $[3,4]$. Сфингомиелин так же является эфффективным ингибитором кишечной абсорбции холестерина [5]. Так же, фоссролипиды влияют на многочисленные клеточные функции, такие как их рост и развитие, молекулярные транспортные системы и развитие болезни Альцгеймера [6].

Лактоза пахты нормализует процессы брожения - предупреждает развитие гнилостных процессов и аутоинтоксикации. Пахта рекомендуется для широкого внедрения в практику питания всех возрастных групп, в т.ч. при гипокинезии (длительной фризической ненагруженности).

Специфической особенностью пахты, в сравнении с обезжиренным молоком, является более высокое содержание мелкодисперсного молочного жира (примерно в 10 раз) и повышенная биологическая ценность, что связано с качественной характеристикой липидного комплекса.

Молочный жир пахты тонко диспергирован, основная масса жировых шариков не превышает размеры 1 мкм. В распределении липидного комплекса характерным является преобладание во всех продуктах насыщенных и ненасыщенных триглицеридов. При изготовлении масла методом сбивания сливок в него переходит меньшая часть фоссро-

липидов $(0,76-0,87 \%)$, а в пахту - большая $(1,66-1,70 \%)$. В то же время метод преобразования высокожирных сливок позволяет обогатить масло фоссфолипидами (1,56\%), а в пахте количество их снижается $(0,97 \%)$.

В настоящее время существует технология получения творога «Столового», который вырабатывается из смеси обезжиренного молока и пахты или из пахты путем сквашивания чистыми культурами лактококков или лактококков и термофильных молочнокислых стрептококков с использованием методов кислотной, кислотно-сычужной коагуляции белков с последующим удалением сыворотки самопрессованием и/или прессованием [8]. Проведенный литературно-патентный поиск свидетельствует о недостатке разработок по использованию пахты в производстве творожных изделий и позволяет сделать вывод об отсутствии аналогов разрабатываемого нами продукта.

Таблица 2 - Общее содержание жиров и фоссфолипидов в некоторых молочных продуктах [7]

\begin{tabular}{|c|c|c|c|}
\hline $\begin{array}{l}\text { 홏 } \\
\text { 을 } \\
\text { 읃 }\end{array}$ & 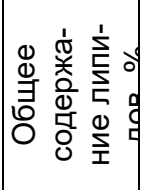 & $\begin{array}{c}\text { Фосфо- } \\
\text { липиды, } \\
\%\end{array}$ & $\begin{array}{c}\text { Количество } \\
\text { фосфолипи- } \\
\text { дов от общего } \\
\text { количества } \\
\text { липидов, \% }\end{array}$ \\
\hline $\begin{array}{l}\text { Цельное } \\
\text { молоко }\end{array}$ & $3-5$ & $0,02-0,04$ & $0,6-1,0$ \\
\hline Сливки & $10-50$ & $0,07-0,18$ & $0,3-0,4$ \\
\hline Масло & $81-82$ & $0,14-0,25$ & $0,16-0,29$ \\
\hline $\begin{array}{l}\text { Топленое } \\
\text { масло }\end{array}$ & $\sim 100$ & $0,02-0,08$ & $0,02-0,08$ \\
\hline $\begin{array}{l}\text { Обезжи- } \\
\text { ренное } \\
\text { молоко }\end{array}$ & $0,03-0,1$ & $0,01-0,06$ & $17-30$ \\
\hline Пахта & 2 & $0,03-0,18$ & 10 \\
\hline
\end{tabular}

Учитывая высокую биологическую ценность пахты, высокое содержание в ней фосполипидов, целесообразна разработка технологии продуктов на ее основе. Нами рассматривается возможность получения творога с адаптированным белковым составом и пониженной жирностью, на основе сухой пахты и обезжиренного молока.

По классической технологии производства творога, массовая доля сухих веществ в сгустке составляет 8-9\%, нами при составлении нормализованной смеси подбиралась такая концентрация сухих веществ, которая позволит исключить технологическую операцию отделения сыворотки и при которой готовый продукт будет не уступать по показателям качества творогу, полученному по традиционной технологии. Кроме того, повыше- 


\section{РАЗРАБОТКА ТЕХНОЛОГИИ ТВОРОЖНОГО ПРОДУКТА С ИСПОЛЬЗОВАНИЕМ СУХОЙ ПАХТЫ}

ние сухих веществ в сгустке будет способствует повышению биологической ценности белковой составляющей в готовом продукте

Объектами исследования были сухая пахта, обезжиренное молоко и закваска. В ходе экспериментальных исследований были приготовлены образцы смеси на основе сухой пахты (м.д.ж. 6\%) и обезжиренного молока (м.д.ж. 0,1\%) с содержанием сухих веществ в количестве от 14 до $26 \%$ с шагом в $2 \%$. В подготовленную смесь вносили закваску для творога в количестве 5 и 10\%, состоящую из культур Lactococcuslactissubsp. lactis, Lactacoccus lactis subsp.cremoris, Streptococcus thermohilus. В полученных сгустках определяли органолептические показатели, титруемую кислотность и влагоудерживающую способность.

При использовании закваски в количестве $10 \%$, образцы с содержанием сухих веществ в количестве 24 и $26 \%$ обладали однородной, ненарушенной консистенцией с небольшим отделением сыворотки, однако в этих образцах ощущался посторонний вкус и запах, не свойственные кисломолочным. Образцы с массовой долей сухих веществ в 14 , $16,18,20$ и $22 \%$, имели однородную консистенцию, сгустки были не нарушены, отделение сыворотки отсутствовало. Вкус и запах этих образцов были чистыми, кисломолочными, с незначительным привкусом сухой пахты.

При использовании закваски в количестве $5 \%$, в образцах с м.д. сухих веществ в 22, 24 и 26\% наблюдалось отделение сыворотки и недостаточно густая консистенция. Тогда как образцы с м.д. сухих веществ в 14 , 16, 18 и 20\% обладали однородной, нежной консистенцией, отделение сыворотки отсутствовало, вкус и запах образцов были чистыми, кисломолочными, без посторонних привкусов и запахов.

В результате экспериментальных исследований по определению органолептических показателей полученных сгустков, нами рекомендована массовая доля сухих веществ $22 \%$, при использовании $10 \%$ закваски и $20 \%$ сухих веществ при использовании закваски в количестве 5\%. Данное содержание сухих веществ в сгустках не оказывает отрицательного влияния на органолептические показатели и позволяет минимизировать дальнейшее отделение сыворотки.

Результаты по определению титруемой кислотности и влагоудерживающей способности опытных образцов представлены на рисунках $1,2,3$.

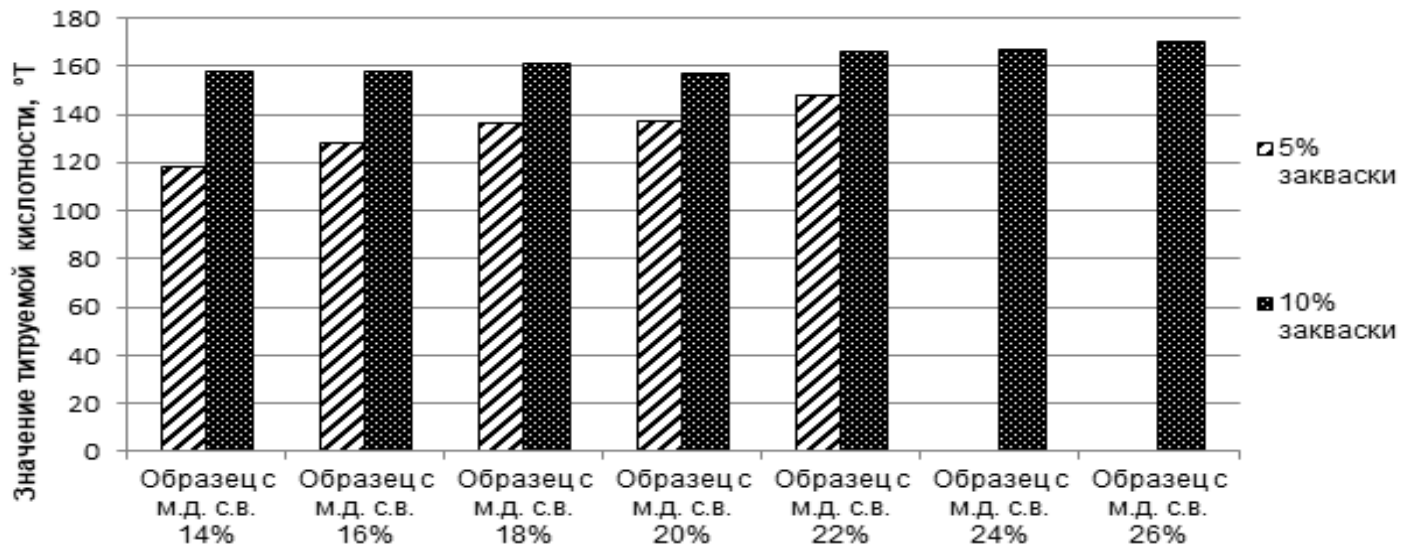

Рисунок 1 - Титруемая кислотность образцов с 5 и 10 \% закваски

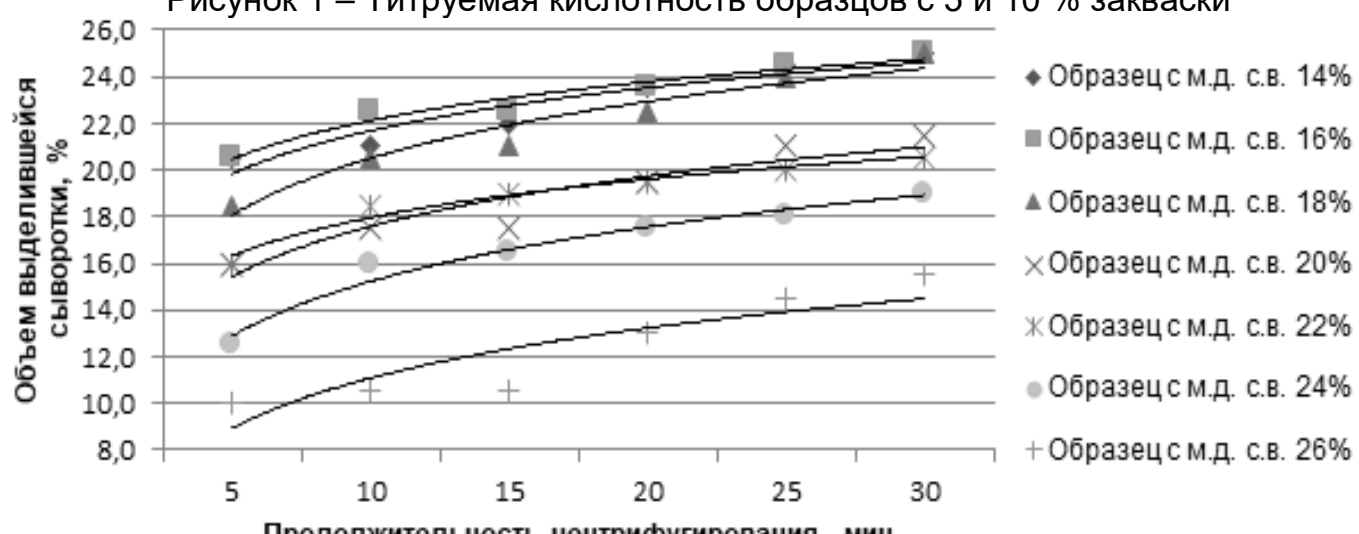

Продолжительность центрисругирования, мин

Рисунок 2 - Влагоудерживающая способность сгустков с 10\% закваски 


\section{Ю.К. НАСОНОВА, Т.П. АРСЕНЬЕВА, Е.А. РОЩИНА,}

В.С. МУХАМЕДОВА, А.И. ЛЕПЕШКИН

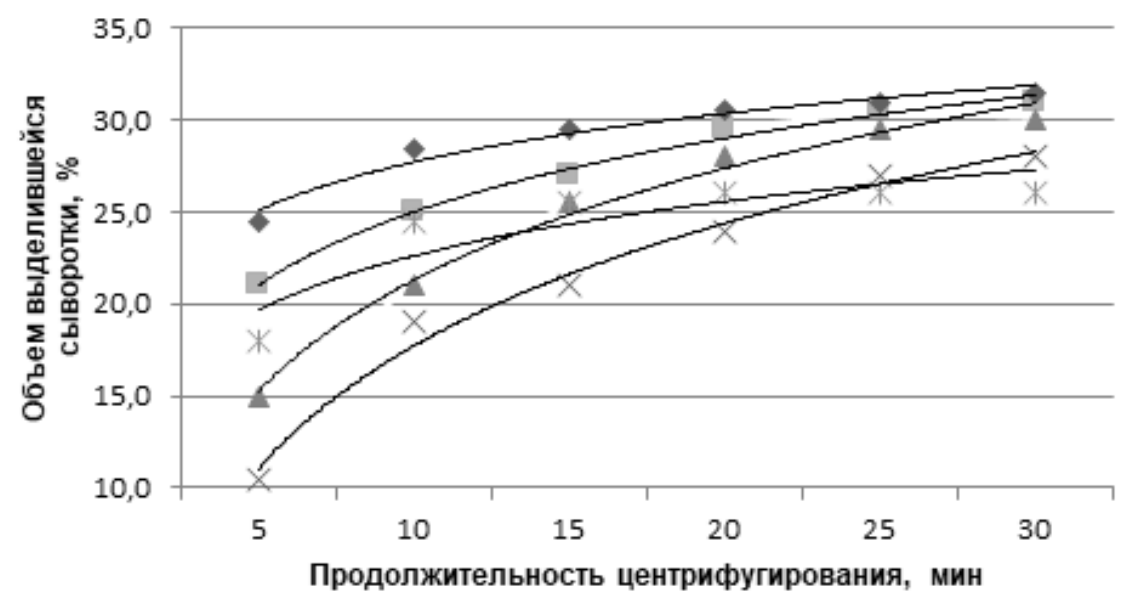

- Образец см.д. с.в. $14 \%$

- Образец см.д. с.в. $16 \%$

- Образецсм.д. с.в. $18 \%$

Образец с м.д. с.в. $20 \%$

Образец см.д. с.в. $22 \%$

Рисунок 3 - Влагоудерживающая способность сгустков с 5\% закваски

Влагоудерживающая способность образцов сгустков с 5 и 10\% закваски представлена на рисунках 2 и 3.

Как видно из данных, представленных на рисунках 2 и 3, с увеличением массовой доли сухих веществ в сгустках увеличивалась их влагоудерживающая способность, при этом все исследуемые образцы обладали довольно высокой влагоудерживающей способностью, отделение сыворотки на протяжении всего периода центрифугирования было равномерным.

Следующим этапом был расчет биологической ценности белковой составляющей проектируемого продукта. Биологическая ценность белка - показатель качества, характеризующий степень задержки азота и эффективность его утилизации для растущего организма или для поддержания азотистого равновесия у взрослых. Качество белка определяется наличием в нем полного набора незаменимых аминокислот в определенном соотношении как между собой, так и с заменимыми аминокислотами. Для выражения биологической ценности белковых продуктов используют метод, основанный на сравнении результатов определения аминокислотного состава белков исследуемого продукта с «идеальным» белком, например, метод аминокислотного скора.

Для оценки биологической ценности использовали основополагающие показатели и критерии, предложенные академиками РАСХН И.А. Роговым и Н.Н. Липатовым [10], такие как: коэфффициенты различий аминокислотного скора (КРАС) и биологической ценности (БЦ), данные представлены в таблице 3.

Таблица 3 - Аминокислотный состав и аминокислотный скор белков разрабатываемого продукта (м.д. с.в. $-22 \%$ )

\begin{tabular}{|c|c|c|c|c|c|c|c|}
\hline \multirow{2}{*}{$\begin{array}{l}\text { Незаменимые } \\
\text { аминокислоты }\end{array}$} & \multicolumn{2}{|c|}{$\begin{array}{c}\text { граммы аминокислот в } 100 \text { г } \\
\text { белка }\end{array}$} & \multirow{2}{*}{$\begin{array}{c}\text { Амино- } \\
\text { кис- } \\
\text { лотный } \\
\text { скор }\end{array}$} & \multirow{2}{*}{$\begin{array}{c}\text { Мин. } \\
\text { амино- } \\
\text { кис- } \\
\text { лотный } \\
\text { скор }\end{array}$} & \multirow[b]{2}{*}{$\triangle \mathrm{PAC}$} & \multirow[b]{2}{*}{ KPAC } & \multirow[b]{2}{*}{ БЦ } \\
\hline & $\begin{array}{l}\text { ФАО/BO3 } \\
2007\end{array}$ & $\begin{array}{l}\text { Белок расчетного } \\
\text { продукта }\end{array}$ & & & & & \\
\hline Гистидин & 1,5 & 2,4 & $162 \%$ & \multirow{9}{*}{$118 \%$} & \multirow{9}{*}{$524 \%$} & \multirow{9}{*}{$58 \%$} & \multirow{9}{*}{$42 \%$} \\
\hline Изолейцин & 3,0 & 4,7 & $157 \%$ & & & & \\
\hline Лейцин & 5,9 & 9,8 & $166 \%$ & & & & \\
\hline Лизин & 4,5 & 7,5 & $167 \%$ & & & & \\
\hline Метионин+Цистеин & 2,2 & 5,3 & $240 \%$ & & & & \\
\hline Фенилаланин+Тирозин & 3,8 & 8,8 & $231 \%$ & & & & \\
\hline Треонин & 2,3 & 2,7 & $118 \%$ & & & & \\
\hline Триптофран & 0,6 & 1,2 & $203 \%$ & & & & \\
\hline Валин & 3,9 & 5,6 & $143 \%$ & & & & \\
\hline
\end{tabular}

На основании проведенных расчетов можно сделать вывод об отсутствии в про- дукте лимитирующих аминокислот, однако, биологическая ценность белковой составля- 


\section{РАЗРАБОТКА ТЕХНОЛОГИИ ТВОРОЖНОГО ПРОДУКТА С ИСПОЛЬЗОВАНИЕМ СУХОЙ ПАХТЫ}

ющей разрабатываемого продукта находится на недостаточно высоком уровне, поэтому является целесообразным поиск дополнительных сырьевых источников белка.

\section{СПИСОК ЛИТЕРАТУРЫ}

1. Britten et al., 2008 M. Britten, S. Lamothe, G. Robitaille. Effect of cream treatment on phospholipids and protein recovery in butter-making process. International Journal of Food Science and Technology, 43 (2008), pp. 651-657

2. R.Rombaut, J.V.Camp, K.Dewettinck. Analysis of Phospho- and Sphingolipids in Dairy Products by a New HPLC Method Author links open overlay panel. Journal of Dairy Science, Volume 88, Issue 2, February 2005, Pages 482-488.

3. Parodi, P.W. Cows' milk fat components as potential anticarcinogenic agents. Journal of Nutrition, 127, 1997, 1055-1060.

4. Gill, H.S.\&Cross, M.L. Anticancer properties of bovine milk. British Journal of Nutrition, 84, 2000, S161-S166.

5. Noh, S.K.\&Koo, S.L.(2004). Milk sphingomyelin is more effective than egg sphingomyelin in inhibiting intestinal absorption of cholesterol and fat in rats. Journal of Nutrition 137,pp. 2611-2616.

6. Spitsberg, V.L. (2005). Bovine milk fat globule membrane as a potential nutraceutical. Journal of Dairy Science, 88, 2289-2294.

7. Fox, P.F., Uniacke-Lowe, T., McSweeney, P.L.H., O'Mahony, J.A. Dairy Chemistry and Biochemistry. 2015

8. ТУ 9222-403-00419785-05. Творог столовый. [Электронный ресурс] - Режим доступа: http://vnimi.org/product info.php?products id=334, свободный.

9. Надточий Л.А., Арсеньева Т.П., Букачакова Л.Ч. Витаминный состав и биологическая цен- ность Алтайского кисломолочного напитка чеген. Научный журнал НИУ ИТМО. Серия: Процессы и аппараты пищевых производств. 2014. № 4(22). С. $1-6$.

10.Забодалова Л.А., Надточий Л.А. Проектирование состава многокомпонентных пищевых продуктов. Ч.1: Учеб. - метод. пособие.- СПб: НИУ ИТМО; ИХиБТ, 2012.- 24 с.

Насонова Юлия Константиновна, ведущий инженер кафедры прикладной биотехнологии Университет ИТМО, 191002, СанктПетербург, ул. Ломоносова, 9; e-mail: umkai666@yandex.ru, тел: +7(981)955-03-82.

Арсеньева Тамара Павловна, Ә.т.н., профрессор кафредры прикладной биотехнологии Университет ИТМО, 191002, СанктПетербург, ул. Ломоносова, 9; e-mail:tamaraarseneva@mail.ru, тел: +7(921)443-30-32

Рощина Елизавета Анатольевна, бакалавр кафеедры прикладной биотехнологии Университет ИТМО, 191002, СанктПетербуре, ул. Ломоносова, 9; e-mail lizarosch97@gmail.com, тел: +7(999)216-96-64

Мухамедова Вера Сергеевна, магистрант кафедры прикладной биотехнологии Университет ИТМО, 191002, СанктПетербуре, ул. Ломоносова, 9; e-mail: vera.veravnl@gmail.com, тел: +7(911)170-28-92

Лепешкин Артем Ильчч, аспирант кафредры прикладной биотехнологии, Университет ИТМО, 191002, Санкт-Петербург, ул. Ломоносова, 9; тел: +7(921)786-23-29. E-mail:spamificotor94@gmail.com. 